\title{
Editorial
}

\section{La transformación de las ciudades}

Cada vez se abre espacio con más fuerza la idea de que las municipalidades deben asumir un mayor protagonismo en el quehacer de las sociedades contemporáneas. En Europa es donde se perfila con mayor nitidez el nuevo rol de las grandes ciudades, las cuales —n opinión de algunos especialistas- deben responder a cinco tipos de retos: nueva base económica, infraestructura urbana, calidad de vida, integración social y gobernabilidad. Grandes ciudades como Barcelona (España), Lisboa (Portugal) y Montpellier (Francia), han encarado con determinación esos desafíos, para lo cual han sido clave dos factores: $(a)$ la construcción de un proyecto de ciudad, en cuyo diseño y puesta en marcha participan conjuntamente tanto el gobierno local como los principales actores económicos, socio-políticos y académicos; y $(b)$ un liderazgo fuerte y personalizado, como el ejercido por los alcaldes de las municipalidades que se han puesto a la cabeza de la renovación de la ciudad.

Como hacen notar los especialistas Jordi Borja y Manuel Castells -en su investigación Local y global: la gestión de las ciudades en la era de la información. Madrid, Taurus, 1997- tres son los factores que han hecho posible la transformación de las grandes ciudades europeas: “( $a)$ la sensación de crisis agudizada por la toma de conciencia de la globalización de la economía; (b) la concertación de los actores urbanos, públicos y privados, y la generación de un liderazgo local (político y cívico); y (c) la voluntad conjunta y el consenso ciudadano para que la ciudad dé un salto adelante, tanto desde el punto de vista físico como económico, social y cultural". 
En América Latina también se han hecho presentes los impulsos transformadores de las municipalidades. En varias de sus ciudades - Bogotá (Colombia), Río de Janeiro (Brasil), Santiago (Chile) y México D.F.— se dibujan algunos factores claves para la recuperación de las mismas como espacio de convivencia ciudadana, polo de atracción turística y lugar de oportunidades económicas. Estos factores son los siguientes: (a) reforzamiento y legitimidad de los gobiemos locales a partir de los procesos de democratización y descentralización de los Estados; (b) movilización de los actores económicos en el marco de la apertura económica; $(c)$ aceptación por parte de los actores públicos y privados de lo inviable que es una ciudad que excluye y margina a buena parte de sus habitantes; $(d)$ creación de un clima de concertación ciudadana en el que se involucren los gobiemos locales, los sectores políticos, intelectuales, profesionales y organizaciones sociales populares; y $(e)$ visión de la ciudad como un espacio simbiótico (poder político-sociedad) y simbólico que se convierte en ámbito de respuestas posibles a los retos económicos, políticos y culturales en una era globalizada.

Así pues, las grandes ciudades europeas y latinoamericanas embarcadas en su propia transformación se han dotado para ello de un proyecto de ciudad que no sólo supone, en su elaboración y ejecución, el apoyo de los principales actores económicos, políticos y sociales, sino también la redefinición de las competencias y organización del gobiemo local, sus mecanismos de relación con otras administraciones y los ciudadanos, su imagen y presencia internacionales.

¿Qué sucede en El Salvador? ¿En qué estado se encuentra la transformación de su ciudad más importante en vistas a los desafíos que plantean tanto su propio crecimiento y deterioro como los desafíos de un mundo globalizado? Para decirlo sin mayores preámbulos, el impulso transformador proveniente de Europa y de las principales ciudades latinoamericanas apenas comienza a echar raíces en nuestro país. Y lo está haciendo en un ambiente político y económico adverso, lo cual es, a la vez, preocupante y meritorio. Preocupante porque sin los consensos mínimos entre el gobierno local, los actores empresariales, el apoyo de profesionales e intelectuales y la participación ciudadana, un proyecto de ciudad no puede elaborarse ni ponerse en marcha. A estas alturas, ese consenso todavía no se ha alcanzado, siendo como es que ni los actores empresariales ni la sociedad civil han asumido con la debida seriedad los desafíos y compromisos que supone la transformación de la ciudad más importante del país.

Asimismo, es meritorio haber comenzado, aunque sea lentamente, la transformación de San Salvador, sobre todo porque ese proceso se ha iniciado y sostenido gracias al esfuerzo casi exclusivo de las autoridades municipales, especialmente del alcalde Héctor Silva. En efecto, contando sólo con el apoyo de unos pocos y en un clima de abierto rechazo a las iniciativas municipales - tanto por parte de grupos de poder económico, reacios a contribuir con lo que les corresponde en la recuperación de San Salvador, como por parte de grupos sociales 
populares, acostumbrados al desorden, a la suciedad y al hacinamiento-, el proyecto de recuperación de San Salvador se ha abierto paso. Con ello, el alcalde Silva y su Concejo Municipal han puesto a la ciudad de San Salvador en la ruta de las transformaciones que hoy por hoy caracterizan a las grandes ciudades de Europa y América Latina.

¿Está asegurada la transformación de la ciudad de San salvador? Es evidente que no. La actual administración municipal apenas ha dado los primeros pasos; los consensos fundamentales todavía están por establecerse; la ciudadanía todavía no se involucra de lleno en la recuperación de su ciudad; el gobiemo central no parece asumir en serio la necesidad de trasladar competencias y responsabilidades - con los recursos debidos- a la municipalidad. Es decir, la transformación de San Salvador es apenas incipiente y requerirá de mucho apoyo y energía para antibar a buen término: una ciudad que, además de espacio de convivencia humana, sea un lugar seguro y atractivo para determinadas iniciativas económicas.

Una condición imprescindible para que la capital del país continúe en la ruta iniciada por la actual administración municipal es que cuente con un buen alcalde. Para serlo se necesita tener una visión de conjunto de los cambios que se están operando en el entomo mundial, así como de los problemas más graves de la ciudad, y una firme determinación de responder ante unos y otros. ¿Cuál de los candidatos que se preparan para competir por el gobiemo municipal cuenta con estas credenciales? Ojalá y seamos lúcidos a la hora de responder a esta pregunta, pues en ello nos jugaremos, en las elecciones del próximo año, el futuro de San Salvador. 